\title{
1960年代に打ける「根性」の変容に関する一考察： 東京オリンピックが果たした役割に着目して
}

\author{
岡部 祐介1）友添 秀則 2 春日 芳美 ${ }^{3)}$
}

Yusuke Okabe ${ }^{1}$, Hidenori Tomozoe ${ }^{2}$ and Yoshimi Kasuga ${ }^{3}$ : The transformation of konjo in the 1960s, focusing on the role to The Tokyo Olympic Games. Japan J. Phys. Educ. Hlth. Sport Sci. 57: 129-142, June, 2012

\begin{abstract}
Konjo is the willpower necessary to endure suffering, and for making an effort, having become a word in daily use in society, as well as in sports. The purpose of this study was to clarify the opportunity and the factors responsible for the transformation of konjo in Japanese society in the 1960s. Our study focused on three points: 1) Clarifying how the meaning of the word konjo changed in the 1960s, from its dictionary definition and usage in newspaper articles. 2) Clarifying the situation in which konjo became popular through the Tokyo Olympic Games, and its spread to the sports community and to society. 3) Considering the factors responsible for the transformation of konjo, and to propose a hypothesis that could account for it.

Our conclusions were as follows: 1) The meaning of konjo evolved from a negative context of "a fundamental character and mindset with which a person is born" to a positive context of "a strong, resilient character that cannot be suppressed" and "a strong motivation to accomplish an aim" at the beginning of the 1960s. 2) Konjo was considered to the spiritual keynote for athletes at the Tokyo Olympic Games. Hirobumi Daimatsu's "konjo theory" had the persuasive reason by winning "Oriental Witches" championship at the Tokyo Olympics. In view of these factors, we considered that konjo was interpreted as a popularized moral virtue by society, and impacted on both education and popular culture. 3) We considered that the concept of konjo became transformed and was used to promote competitiveness in sports at the Tokyo Olympics as part of the strategy for "character building”'. It also played a role in bolstering human resources that played a key role in economic development during the 1960s, and thus was of strategic value. The considerations listed above show that the Tokyo Olympic Games played an important role in the transformation of the concept of konjo in the 1960s.
\end{abstract}

Key words : high-speed economic growth, sport, spiritualism, hirobumi daimatsu, character building キーワード : 高度経済成長, スポーツ, 精神主義, 大松博文, 人間形成

\section{I .はじめに}

\section{1. 本研究の目的}

「根性」とは，苦しみに耐え抜いて努力する精 神力のことをさし，現在ではスポーツをはじめ日 常的に使用されている言葉であるといえる. 一方

1) 早稲田大学スポーツ科学研究センター

干359-1192 埼玉県所沢市三ヶ島 2-579-15

2) 早稲田大学スポーツ科学学術院

干359-1192 埼玉県所沢市三ヶ島 2-579-15

3) 早稲田大学大学院スポーツ科学研究科

干359-1192 埼玉県所沢市三ヶ島 2-579-15

連絡先 岡部祐介
で，わが国では「根性」という言葉によって示さ れる精神性が，これまでスポーツに対する見方・ 考え方の特質として取り上げられてきた. スポー ツにおける「根性」は，「精神主義」「修養主義」 （岸野，1968，菅原，1976）や「苦しみのスポー ツ価值意識」（上杉，1982），「苦行的スポーツ」 （デビットノッター・竹内，2001）といった表現

1. Waseda Institute for Sport Sciences 2-579-15 Mikajima, Tokorozawa, Saitama 359-1192

2. Faculty of Sport Sciences, Waseda University 2-579-15 Mikajima, Tokorozawa, Saitama 359-1192

3. Graduate School of Sport Science, Waseda University 2-579-15 Mikajima, Tokorozawa, Saitama 359-1192 Correspondingauthory.okabe@kurenai.waseda.jp 
で示される性質と類似するものとして考えること ができ，いわゆる「日本的スポーツ」論注1)の範 疇に位置づけられるといえる。

しかし，この「根性」という言葉に着目し，意 味使用の変遷に着目した研究や，スポーツにおけ る「根性」を取り上げ，その変容過程に着目した 研究は，管見では僅少であるといえる．学術的な 研究では，たとえば松田（1971）や中込（1984） をはじめとしたスポーツ心理学の立場から，「根 性」のメカニズムとその養成方法について考察し た研究成果が確認できる，また，山岸ほか(1979) は, 社会心理学の立場から, 高度成長期の社会心 理として「根性主義」を指摘して抢り，歴史的な 分析と構造的な特質について考察をおこなってい る．坂上（2001）は，「根性」が1964(昭和39)年 の東京オリンピックを重要な契機として流行し， 高度経済成長を支えた日本人の精神的支柱として 定着していったという見解を述べている。しか し，これらの研究では，1960年代に打ける「根 性」の意味使用の変容およびその要因や，スポー ツにおける「根性」の成立および定着状況につい ての重点的かつ実証的な分析は十分でないと考え られる。

そこで本研究では, 山岸らの用いた「根性主義」 や日常的に使用されている「根性」とは差異化さ れた，スポーツにおける「根性」の特質をどのよ うに示すことができるのかということを念頭に置 き，わが国の1960年代に抢ける「根性」の意味 使用が変容した契機を明らかにすることを目的と する。とりわけ，東京オリンピックを契機として スポーツ界において「根性」が取り上げられた経 緯を子まえ「根性」の意味使用の変容にスポー ツおよび東京オリンピックが重要な役割を果たし たことを明らかにしたい。そのために，本研究で は次の課題を設定し，考察を行なうこととする. すなわち，1）1960年代に「根性」という言葉の 意味使用が変化したことを辞書的定義や新聞記事 における使用状況の変遷から明確化し，2) 東京 オリンピックを契機に「根性」が取り上げられ， スポーツ界抢よび社会に普及していった状況を明 確化する，1），2）の考察をふまえ，3）1960年代
に抢ける「根性」の意味使用が変容した要因を仮 説的に提示することとする。

\section{1960年代の精神史的背景と東京オリンピッ ク}

上述のように設定した課題について考察を進め ていく前提として，本研究において焦点化する 1960年代という時代の精神性, 社会通念につい て概観し，「根性」の意味使用の変容抢よび東京 オリンピックという事象との関係を示しておく.

本研究に抢ける考察の中心的な対象時期となる 1960年代は，戦後のわが国における高度経済成 長が明確な足取りのものとなり，大衆（消費）社 会とよばれる状況が特徵的に示される時期である といえる.この時期には, 経済状況は戦前の水準 をこえ，めざましい復興を遂げたといえよう。し かし，精神状況についていえば，1945（昭和20) 年の敗戦時からは回復していないことが指摘され ている（竹内，1959，pp. 1-6)注2)。見田（1965） は，1960年代の精神状況に着目するうえでは， 1945 (昭和 20 ) 年の敗戦による挫折・喪失に新た な地点からたえず立ち返ること，その意味を繰り 返し深めていくことが肝要であると述べている （見田， 1965，pp. 140-141）。「根性」の意味使 用の変容と東京オリンピックをめぐる精神状況に ついては，上述のように敗戦による挫折・喪失体 験を関連づけることができる。

五十嵐（2007）によれば，敗戦による挫折・ 喪失の記憶注3) は, 戦後日本の文化的なアイデン ティティの構築にとって根本的なものとして存在 してきたと考えられている，五十嵐は，東京オリ ンピックによって喪失の記憶は次のように変容し ていったと述べている.

「オリンピックという華々しいスポーッの祭 典は，戦後の日本社会にとって，スポーツ選 手の身体と都市景観を通じて，戦争の記憶を 再編し，衛生的で無害なものにする機会とな ったのである。(中略) 戦争の記憶は依然と して戦後社会とともにあったのだが，それは 日本の戦後の繁栄のための必要条件へと，言 
説のなかで変容されていったのである」（五 十嵐，2007，p. 25)

上述の五十嵐の見解をふまえていえば，東京才 リンピックは, 戦争における挫折・喪失を想起さ せたと同時に，高度経済成長下の1960年代にお ける再建・復興の象徵として位置づけることがで きよう。戦後のわが国に抢ける国際復帰, 高度経 済成長の達成といった再建・復興を支えた精神 は，上述のように戦争による挫折・衰失体験との かかわりによってみいだされる。

山岸ほか（1979）は，東京オリンピックを契 機として1970年初頭まで続いた「根性」という 言葉の流行に着目し, 背景にある当時の社会心理 を「根性主義」として分析の対象とし，安丸 （1974）の民衆思想研究で用いられた「通俗道 徳」注4) との比較に抢いて,「根性主義」を「通俗 道徳の現代版」としてとらえる可能性を示してい る.「通俗道徳」は, 本質的に「建設の倫理」で はなく, 中井（1982）が述べた危機からの「復 興・再建の倫理」または「執着（性）気質的職業 倫理」注5)であったと考えられる。このような背 景・性格のもとで捉えられる「通俗道徳」はまた, 歴史的・階級的に貫通したものであるとも考えら れていることから，「根性主義」が「通俗道徳の 現代版」として捉えられたといえよう.

しかし，山岸らが反省的に述べているように， 近世後期においてみいだされた「通俗道徳」と高 度経済成長期に打ける「根性主義」との類似を指 摘するには，関連する諸言説のより厳密な分析と 考察が必要であるといえる。本研究においては, 「通俗道徳」や「執着気質的職業倫理」が，「根性」 の意味使用の変容および流行を支えた精神状況に も確認されうるものであると仮説的に捉えておく こととする。すなわち，「根性」の意味使用が変 容していく背景には,「通俗道徳」や「執着気質 的職業倫理」と関連する挫折・喪失の危機からの 「再建 ·復興」の時代精神 · 社会通念が認められ るのではないかと考える。このような背景状況を ふまえ, 以下では「根性」の意味使用の变容およ びその要因について考察していくこととする.

\section{III「根性」の辞書的意味および その使用状況の変遷}

ここでは,「根性」という言葉の意味に着目し， 「根性」の意味形成およびその変遷について検討 する。つまり，冒頭で示した 1）1960年代に「根 性」という言葉の意味使用が変化したことを辞書 的定義や新聞記事における使用状況の变遷から明 確化するという課題に取り組んでいく.

はじめに，「根性」の意味が国語辞典注6)におい てどのように説明されてきたのかということにつ いて検討する. 明治時代の初期の代表的な国語辞 典である「言海」（1891，明治24年）には，すで に「根性」の記載が確認できる。その内容は， 「ココロ, ココロネ, ココロノソコ」と記されて いる. 同時期の「日本大辞林」(1894, 明治27年) も同様の内容が記載されている。 また，1928(昭 和 3) 年の「大日本国語辞典」も同様の内容を示 しており，例示には「根性ヨ入レ換ヘル」と記さ れている.「言海」の改訂版として出版された 「大言海」(1933, 昭和 8 年) に抢いても,「ココ ロネ，ココロダテ，性根」といった同様の内容が 記載されている.そこでは「根」と「性」とをそ れぞれ参照との注記があり，「根」の項では，「佛 經ノ語, 人ノ天賦ノ性質, 性能, 根性. 事习行フ 二, 久シク堪へ忍ブ, 精神ノ力. 精力 · 気力」, 「性」の項では，「人ノウマレツキノ性質・性分」 という記載がある。その後, 1934 (昭和 9)年の 「広辞林」, 1935 (昭和10)年の「辞苑」, 1938 (昭 和13)年「言苑」, 戦後は 1959 (昭和 34$)$ 年の「新 言海」にいたるまで記載内容の変化はなかった. また，用語の例示からは，「根性腐り」や「根性 悪」,「根性を入れ換える」などの語が確認され， 「根性」という言葉は必ずしも肯定的な用語を伴 って使用されていなかったことが考えられる.

現在の「根性」の意味を辞書にもとめると, 2008 (平成 20 ) 年の広辞苑第 6 版では「その人の 根本的な性質.こころね. しょうね」, 「困難にも くじけない強い性質」という $2 つ 0$ 意味の記載 が確認できる，広辞苑において後者の意味が記載 
されたのは 1983 (昭和 58 ) 年第 3 版からであっ た。また, 1974 (昭和49)年の日本国語大辞典で は，「苦しみや困難に耐え，事を成し遂げようと する強い気力, 根気」という意味内容が加えられ た注7).

上述のことから，「根性」は戦前から戦後のは じめにかけて，ひとつには「こころだて，こころ ね, しょうね」といった，人間性や人間の本質的 な部分，先天的に備わった性質といった意味の言 葉として使用されていたことが考えられる。いま ひとつは，1933(昭和 8)年の「大言海」の「根」 の項にみられたように，「事を行なうに，久しく 耐え忍ぶ精神の力」という意味が付与されていた ことが考えられる。しかし，「大言海」の後の 「辞苑」や「言苑」では，「根性」の項で「事を行 なうに，久しく耐え忍ぶ精神の力」という記載は 確認されていないことから，「根性」は一般的に 前者の意味で使用されていたことが推察される. そして，「困難にくじけない強い性質」，「事を成 し遂げようとする強い気力」といった意味で一般 的に用いられるようになるのは，1970年代前後 のことであると考えられる．このような「根性」 の辞書的な意味の変遷をふまえ，以下では新聞記 事注8)を中心として「根性」という言葉の使用状 況に着目する.

表 $1 ， 2$ は，朝日・読売両紙における「根性」 という言葉の記載件数抢よび意味使用の分類を示 している．意味使用の分類については，上述の国 語辞典に抢ける記載内容を子まえ，次のように行 なった，意味 Aについては，「こころだて，ここ ろね，しょうね」といった，人間性や人間の本質 的な部分, 先天的に備わった性質といった意味 で，主に否定的な用語や文脈を伴って用いられて いる「根性」を，意味 B については，「困難にも くじけない強い性質」，「事を成し遂げようとする 強い気力」といった意味で，主に肯定的な文脈で 用いられている「根性」を示している。

表によれば，両紙ともに創刊年から「根性」の 記載が確認できる。しかし, 戦前の記載件数に比 べて, 戦後の1960年代からの記載件数に急激な 増加がみられる，意味使用については，両紙とも
表 1 朝日新聞における「根性」の使用状況

\begin{tabular}{|c|c|c|c|c|}
\hline 年 & 記事件数 & 意味 A & 意味 B & その他 \\
\hline $\begin{array}{l}1879(\text { 明治 } 12) \text { 年一 } \\
1890(\text { 明治 } 23) \text { 年 }\end{array}$ & 3 & 3 & 0 & 0 \\
\hline $\begin{array}{l}1891 \text { (明治 } 24) \text { 年一 } \\
1911(\text { 明治 } 44) \text { 年 }\end{array}$ & 63 & 62 & 0 & 1 \\
\hline $\begin{array}{l}1912 \text { (大正元)年一 } \\
1925 \text { (大正14)年 }\end{array}$ & 50 & 50 & 0 & 0 \\
\hline $\begin{array}{l}1926 \text { (昭和元) 年一 } \\
1945 \text { (昭和 } 20) \text { 年 }\end{array}$ & 42 & 41 & 0 & 1 \\
\hline $\begin{array}{l}1946 \text { (昭和 } 21) \text { 年一 } \\
1959 \text { (昭和 } 34) \text { 年 }\end{array}$ & 18 & 18 & 0 & 0 \\
\hline 1960 (昭和35)年 & 4 & 1 & 3 & 0 \\
\hline 1961 (昭和36)年 & 2 & 0 & 2 & 0 \\
\hline 1962 (昭和 37 )年 & 1 & 0 & 1 & 0 \\
\hline 1963(昭和38)年 & 13 & 3 & 9 & 1 \\
\hline 1964(昭和39)年 & 18 & 1 & 17 & 0 \\
\hline 1965(昭和40)年 & 12 & 2 & 9 & 1 \\
\hline 1966(昭和41)年 & 10 & 4 & 6 & 0 \\
\hline 1967 (昭和 42 )年 & 13 & 0 & 13 & 0 \\
\hline 1968(昭和43)年 & 11 & 1 & 10 & 0 \\
\hline 1969 (昭和 44$)$ 年 & 6 & 1 & 5 & 0 \\
\hline 1970 (昭和45)年 & 11 & 0 & 11 & 0 \\
\hline 1971(昭和46)年 & 16 & 1 & 15 & 0 \\
\hline 1972(昭和47)年 & 5 & 1 & 4 & 0 \\
\hline 1973(昭和48)年 & 5 & 0 & 5 & 0 \\
\hline 1974(昭和49)年 & 9 & 0 & 9 & 0 \\
\hline 1975(昭和50)年 & 7 & 0 & 7 & 0 \\
\hline 1976(昭和51)年 & 9 & 0 & 9 & 0 \\
\hline 1977 (昭和52)年 & 4 & 2 & 2 & 0 \\
\hline 1978(昭和53)年 & 2 & 1 & 1 & 0 \\
\hline 1979 (昭和54)年 & 6 & 0 & 6 & 0 \\
\hline 1980 (昭和55)年 & 5 & 0 & 5 & 0 \\
\hline 計 & 345 & 192 & 149 & 4 \\
\hline
\end{tabular}

に戦前における意味 Bの使用は確認されなかっ た。

記事の内容をみていくと，戦前では朝日新聞の 創刊年である 1879 (明治 12$)$ 年の大阪版朝刊の記 事において，すでに「忿張根性」という使用が確 
表 2 読売新聞における「根性」の使用状況

\begin{tabular}{|c|c|c|c|c|}
\hline 年 & 記事件数 & 意味 A & 意味 B & その他 \\
\hline $\begin{array}{l}1875(\text { 明治 } 8) \text { 年一 } \\
1890(\text { 明治 } 23) \text { 年 }\end{array}$ & 21 & 15 & 0 & 6 \\
\hline $\begin{array}{l}1891 \text { (明治 } 24) \text { 年一 } \\
1911(\text { 明治 } 44) \text { 年 }\end{array}$ & 32 & 31 & 0 & 1 \\
\hline $\begin{array}{l}1912 \text { (大正元)年一 } \\
1925 \text { (大正14)年 }\end{array}$ & 22 & 21 & 0 & 1 \\
\hline $\begin{array}{l}1926 \text { (昭和元) 年一 } \\
1945 \text { (昭和 } 20) \text { 年 }\end{array}$ & 49 & 40 & 0 & 9 \\
\hline $\begin{array}{l}1946 \text { (昭和 } 21) \text { 年一 } \\
1959 \text { (昭和34)年 }\end{array}$ & 65 & 46 & 0 & 19 \\
\hline 1960 (昭和35)年 & 5 & 2 & 0 & 3 \\
\hline 1961(昭和36)年 & 9 & 2 & 6 & 1 \\
\hline 1962 (昭和37)年 & 7 & 4 & 3 & 0 \\
\hline 1963(昭和38)年 & 28 & 9 & 19 & 0 \\
\hline 1964(昭和39)年 & 42 & 12 & 24 & 6 \\
\hline 1965(昭和 40 )年 & 47 & 10 & 32 & 5 \\
\hline 1966(昭和41)年 & 16 & 5 & 9 & 2 \\
\hline 1967 (昭和 42 ) 年 & 30 & 8 & 18 & 4 \\
\hline 1968 (昭和 43 )年 & 35 & 14 & 19 & 2 \\
\hline 1969 (昭和 44$)$ 年 & 24 & 4 & 17 & 3 \\
\hline 1970 (昭和 45 )年 & 60 & 19 & 38 & 3 \\
\hline 1971(昭和46)年 & 15 & 2 & 13 & 0 \\
\hline 1972(昭和 47 )年 & 19 & 7 & 12 & 0 \\
\hline 1973(昭和 48 )年 & 11 & 1 & 10 & 0 \\
\hline 1974(昭和49)年 & 12 & 3 & 8 & 1 \\
\hline 1975 (昭和 50 ) 年 & 6 & 0 & 6 & 0 \\
\hline 1976(昭和51)年 & 8 & 1 & 7 & 0 \\
\hline 1977 (昭和 52 ) 年 & 9 & 1 & 8 & 0 \\
\hline 1978(昭和53)年 & 14 & 2 & 12 & 0 \\
\hline 1979 (昭和 54 ) 年 & 14 & 2 & 12 & 0 \\
\hline 1980 (昭和 55 )年 & 8 & 1 & 7 & 0 \\
\hline 計 & 608 & 262 & 280 & 66 \\
\hline
\end{tabular}

認できる。また，読売新聞に関しても，1875(明 治 8) 年の記事に「奴隷根性」という語が確認で きる。ほかにも「土族根性」（朝日新聞 1893 年 9 月 8 日付）や「町人根性」(1894年 2 月 11 日付) という使用が確認できるが，記事ではこれらが否
定的に取り上げられている。 1910 (明治43)年の 朝日新聞では, 気質と「根性」について解説した 記事を確認することができ，「根性と云ふのは気 質よりは狭い悪い意味を有つので商人根性と云へ ば馬鹿に金を儲けたがり義理人情を知らぬ共通習 慣を云ひ百姓根性と云へば握つたら最後鐚一文で も出さないシミツたれな共通習慣を云子」（朝日 新聞1910年 4 月 19 日付）と述べられている. そ の他に戦前の記事における使用例をみると, 窃盗 を犯して刑を受けた者が出所後間もなく再び窃盗 を働いたことに「持つて生れた根性」（朝日新聞 1915年 1 月 24 日付, 同年10月 12 日付）と評した 記事や，「他人に少しでも儲けさせまいとして小 細工を弄する役人根性」（読売新聞1928年 6 月 16 日付）といった記事が確認できる. その後, 戦前 から戦後の1950年代まで記事における使用の変 化は確認されず，主に「島国根性」や「役人根性」, 「ナワバリ根性」といった語が用いられていた。 これらの記事をはじめとして, 明治期から戦後初 期における「根性」は，人間の根本的な性質や気 質といった辞書的意味で使用されていたといえよ う。そして,「奴隷根性」や「鬼畜根性」,「泥棒 根性」などといったように，「根性」は否定的な 用語とともに用いられていた。国語辞典における 使用例では否定的な用語が記載されていたが，新 聞記事においても同様の使用がなされていたとい えよう.

しかし, 戦後になると, 国語辞典におけるもう 一方の意味である「困難にくじけない強い精神」 という使用や肯定的な文脈に拈ける使用が確認で きるようになった．特に，スポーツに関連した記 事において，競技者を称賛するような文脈におけ る使用がなされている。たとえば, 朝日新聞では 1960 (昭和 35$)$ 年に相撲関連の記事において「根 性の人・栃錦」という見出しを揭げており（朝日 新聞1960年 5 月 11 日付), 同年の11月に掲載され た野球関連の記事では，勝利投手が「まさに根性 の男」という見出しで称賛されている（朝日新聞 1960年11月13日付). 読売新聞においても,「プ ロ・テニスの根性」(読売新聞1961年11月 10 日付) という見出しの記事が確認でき, 当時の各スポー 
ツの記事において，「根性と名門の底力」（読売新 聞1961年10月16日付),「ムーアの根性/世界フェ ザー級選手権」（読売新聞1961年11月14日付）と いったように「根性」が用いられている。 また, 1961(昭和36)年には,「根性」という言葉そのも のを取り上げた記事が確認できる。そこでは， 「根性」は昔から使用されてきた言葉であるとし ながらも，「兵隊の訓練や戦争を背景にして『根

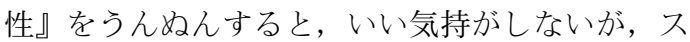
ポーツの場では，この言葉は生気をとりもどす」 （朝日新聞1961年11月 1 日付）と記されている.

上述のように，新聞記事における使用状況か ら，「人間の根本的な性質」を本来の意味として いた「根性」は，1960年代にはその意味使用が 変化していることが確認できる，さらに記事をお っていくと，東京オリンピックが開催された 1964(昭和39)年以降は，「根性」がスポーツを中 心として流行語的にさまざまな場面で用いられて いくことがわかる.

東京オリンピックが開催された1964（昭和39） 年10月には，競技結果を伝える記事に「根性」 が使用されている，たとえば「見事，養った根性 レスリングローマの雪辱」（朝日新聞1964年10 月15日付）や「超人的なアべべの独走 円谷も 根性久せる “ベルリン以来”の快挙」（朝日新聞 1964年10月 22 日付),「猪熊功 根性のカムバッ ク」（読売新聞1964年10月23日付）といった見出 しにあらわれているように，競技者の強勒な精神 をさす言葉として「根性」が用いられている。

東京オリンピック後の朝日新聞社説には，以下 のようにスポーツに抢ける「根性」に関連する記 載が確認できる.

「体格も適性も技術も闘志も運動神経反射も 十分な選手が，自在にエネルギーの持続と配 分を掌中のものとしていることと，“根性” を解析した人があったが，ここまでくると “根性”の中に精神的，心理的，肉体的条件 の総合強化の意味が込められていることにな り，この各条件を良くし要素を鍛えることが トレーニングであることがわかる」（朝日新
聞1964年10月22日付）

上述の記事から，「根性」は競技者の総合的な 強化・育成の基調とされていたことが推察される.

東京オリンピックを前後して, 社会的な側面に おいても「根性」が取り上げられている. 読売新 聞では，「現代の日本人」という特集において， 当時の社会問題として向上意欲の低下や目標の不 在をあげ，現代機械文明の社会では根性を発揮し にくい，いわば「根性」が不要の時代であると記 されている（読売新聞1964年 8 月10日付).この 記事において，「根性」は「目標を達成する強い 意欲」であり，「たゆま努力，忍耐，ねばり… などを伴うもの」であると規定されている．そし て,「根性」はもって生まれた性質というよりも， 社会的環境など後天的にそなわる要素が強いと記 されており，「根性」を「仕事への欲ばり，ある いは欲づくり」ととらえ，「根性」は「社会の期 待にこたえ, 社会の目標を自己の目標とする態度 をつくりあげ，さらに社会的価值を生産するとい う終局目標」であると考えられている（朝日新聞 1964年 6 月 6 日付). 1964 (昭和 39 ) 年以降は, 「テスト主義やめて根性の教育」（読売新聞1965 年 2 月 1 日付) や「根性づくりに養豚」（朝日新 聞1965年10月 22 日付),「合宿で社員に根性」(朝 日新聞1966年 8 月 5 日付）などと報じられてい るように，スポーツ界に限らず，各方面で「根性 づくり」や「根性教育」が取り上げられている.

上述のような新聞記事に打ける使用状況から， 「根性」の意味使用は, それまで主流であった 「生まれついた人間の根本的な性質」という意味 で, 主に否定的な文脈における使用から,「困難 にもくじけない強い性質」, 「事を成し遂げようと する強い気力」といった意味を中心とした使用に 転換していったと考えられる，また，この意味使 用の転換は前項で検討した「根性」の辞書的意味 が変容した時期（1970年代初期）にも概ね対応 しているといえよう注9)。本項に打ける以上の考 察加，1960年代に括いて「根性」は，先天的 に備わった性質から後天的に形成される可能性が 込められた用語へ，また，否定的な用語を伴った 
使用から肯定的な用語を伴った使用へと変容して いったことが実証的に明確化されたといえよう。 また，「根性」の意味使用の転換は，東京オリン ピックを中心としたスポーツ界に端を発している ことが推察された。

\section{III．「根性」の各方面への普及·定着}

これまでの考察をふまえ, 以下では当時のス ポーツ状況に着目し, 特に東京オリンピック開催 にともなうスポーツ体制の成立過程において， 「根性」がどのように取り上げられていったのか を検討していく。つまり，本研究に抢ける課題 2) 東京オリンピックを契機に「根性」が取り上 げられ，スポーツ界打よび社会に普及していった 状況を明確化することを試みる.

\section{1. 東京オリンピックにおける精神的基調と 「根性」}

1961(昭和36)年に組織された東京オリンピッ ク選手強化対策本部（以下「選手強化本部」と表 記する）では，メダルを獲得するための選手強化 の具体的な方針として，「根性つくり」が考えら れた. 選手強化本部スポーツ科学研究委員会心理 部会注10)は，「根性」を，「高い目標意識をもち， その目標達成のために精神を集中しそれを持続す る強烈な勝利への意志」(東京オリンピック選手 強化対策本部，1962，p. 2）と定義している.

東京オリンピックに向けた選手の「根性つくり」 はスポーツ科学研究委員会の心理部会で取り扱わ れていた（スポーツ科学研究委員会, 1965, p. 22). 心理部会では, 発足当初から競技者の「あ がり」の研究や，指導者が競技者の性格を科学的 に把握し，合理的な指導を行なうための性格テス トの方法に関する研究に取り組んでいたが，「あ がり」や競技者の性格特性の問題を, 競技者の精 神面の強化, すなわち「根性」養成の問題に関連 づけた。

スポーツ科学研究委員会の報告書によると，こ の問題は競技者にとどまらず指導者のあり方や指 導方法にも関連することであり，競技者や指導者
の基本的な構えや態度の問題と，競技者の可能性 を最大限に引き出す心理的な基盤の問題として究 明された（スポーツ科学研究委員会, 1965, p. 495)。報告書では, 心理部会で検討された「根 性の意義」「根性のある選手」「根性養成の方法」 についてそれぞれ規定されている．「根性の意義」 においては,「運動選手としては，スポーツの価 值を認め，記録を伸ばすことの意義を認識し，明 確な目標をもって, 自己の行動を統一し, 選手と してあるべき自覚をもち，選手として，社会から 期待されている行動をとれるようにすることが, “根性をつける”ことであると考えられる」(スポー ツ科学研究委員会, 1965, p. 495) という記載が ある，として「根性のある選手」に共通する特徴 については, 勝利というひとつの目標のために練 習に打ち込み，苦しさに耐え，努力を意らないこ とが指摘されている.

選手強化本部の機関誌「OLYMPIA」には，役 員や指導者で構成された座談会の内容が掲載され ている，座談会では各氏による「根性」論が語ら れており，勝利への自信をつけるために「猛練習」 することが重要な要素であると説かれていた（東 京オリンピック選手強化対策本部, 1962, pp. 210).たとえば，当時の水泳連盟会長を務めた高 石勝男は「根性とは自信である」と述べており， 陸上競技の強化コーチを務めた田島直人は「根性 とか精神力とかいうものは, 実力と裏腹なもんな んだと思う。自分の現在の体力では, これ以上出 せそうもないというところまで練習したという自 信である」と述べている，また，当時スポーツ科 学研究委員会委員長の東俊郎は「もともと根性と は, 自信をもつまでの練習をやり続けるための節 制，勇猛心こんなものが混然となってあらわれる ものである」と述べている，このように，「根性」 の養成には徹底的な猛練習が欠かせない要素とさ れた，座談会では，猛練習によって「根性」をも たせるために大切なものはエリートとしての自覚 であるとし，選手たちは選ばれた人間であり，日 本の選手の代表で外国の選手と戦うのだという自 覚と責任感, 誇りがなければならないといわれた.

スポーツ科学研究委員会心理部会の一員であっ 
た太田（1968）は，1964(昭和39)年の東京オリ ンピックに備えた選手強化の過程において，「根 性養成法のテキストの作成」についての要請があ ったことにふれ，その経緯を述べている．太田に よれば，東京オリンピック選手強化対策本部長を 務めた大島鎌吉が，スポーツ科学研究委員会心理 部会に上述のテキスト作成を要請したといわれ， 心理部会の委員たちによって資料が作成されたと いう（太田，1968，p. 44）。大島が選手強化に根 性を持ち込んだ理由については，当時の紙面にお いて以下のように述べられている.

「試合で選手の能力をフルに発揮させるのは 結局のところは，強い意志の力による．精神 力だ。そのことは経験的にはわかっていた が，それをどうやって，選手たちに理解させ るかが問題だった。それには，感情にうった えるのが早道だ。根性という言葉がぴったり だと思った」（読売新聞1965年 3 月 3 日付）

太田によれば，当時は体力づくりが重視され， 一応の体力が形成された後に魂を注入するという 意味から「根性」という言葉が使用されはじめた という. また, 生理学的見地から理論づけられた 体力づくりを，機械のような運動としてではな く，バランスのとれた人間形成の一環として考元 させるねらいもあったという（太田，1968，p. 45). 人間形成の一環としての「根性つくり」と いう考えについては，大島も雑誌の対談におい て，同様のことを述べている．

「日本人の持っているポテンシャルを開発し てみようじゃないかという気があった，その ためにはトレーニングのやり方とかいろいろ 問題があるが，私たちは “人間つくり”とい うコトバを使った．別の人間をつくるのだ. いままでの日本人のスポーツ界にはいなかっ た別の，もっと次元の高い人間をつくろうじ ゃないか，というので，“人間つくり”とい った」（大島，1964，p. 65）
大島が東京オリンピックに打ける選手強化を 「人間つくり」としたことには，スポーツにおけ る日本人の持っている可能性を追求したいという 野心や期待がその根底にあったと考えられる，つ まり，東京オリンピックにおける競技者の精神的 基調としてあげられた「根性」は，スポーツにお ける競技者としての「人間つくり」や「人間形成」 の問題として取り上げられたのであり，選手強化 に抢ける「根性」は，競技者の人間的価値につい ての評価を左右するほどの影響力をもっていたと 考えられる. また，スポーツ科学研究委員会によ って規定された「根性」とは, 勝利という目標達 成のために精神を集中し，困難に屈せず継続する 強固な意志のことであり，その養成には，ハード トレーニングといわれる猛練習が重視されたとい えよう.

以上のことから，「根性」の意味使用が変容し ていく背景には，東京オリンピックを成功に導く ための，スポーツ界の積極的なはたらきかけが関 連していたことが考えられる。すなわち，戦後の スポーツ体制とりわけ東京オリンピック体制が整 備されていった過程に抢いて，「根性」は担い手 の精神的基調として戦略的に措定されたといえよ う.

\section{2. 東京オリンピックを中心としたスポーツに おける「根性」論の展開}

次に，「根性」が体育・スポーツの各方面で取 り上げられ，いわゆる「スポーツ根性論」が流行 していく状況について検討する。

東京オリンピックを重要な契機として形成され たと考えられる，意味使用が変化した「根性」は， 競技スポーツ抢よび一流競技者のみならず，一般 大衆が主体となるスポーツや学校体育, 運動部活 動にも浸透していったことが考えられる. 東京才 リンピック後の体育雑誌をみると，『新体育』に おいてスポーツと「根性」についての論稿が揭載 されており，「根性」は競技者のみに必要とされ るものではなく，社会において困難な状況でも強 い意志と実行力で生き抜く力として求められるも のであると考えられている（高橋， 1964，p. 
130)。このとき，「根性」は「道徳的な心の強さ」 （高橋，1964，p. 131）に読み替えられていると いえる。 また，『学校体育』でも1965(昭和40)年 の新年号で「根性」についての論稿を掲載してい るほか，1968(昭和43)年には「体育における精 神的側面」という特集を組み，「根性」を取り上 げている。これらの論稿では，「根性」は「精神 力」とほぼ並列してとらえられ，「これを心的機 能としてとらえ，練習や試合に対する激しい闘志 などの一面と自己の意志，感情を統制して運動に 対して有効に集中したり，コントロールする作用 の一面とを統合した概念」（浅川，1968，p. 22） と考えられている.

丹下（1963）は，ハードトレーニングを自ら 進んでやり抜く「根性」のある競技者をスポーツ 的人間ととらえ，オリンピック代表候補選手たち の雾囲気が，そのまま社会的な雾囲気となり，ト ップレベルの競技スポーツに限らず，小学校から 大学まで学校スポーツにも及んでいると主張して いる（丹下，1963，pp. 152-154）。このような 人間づくりは，自然に形成されるものではなく， 「主として運動クラブ指導教官, 先輩, 部員たち によって絶えず強力に行われる指導によって形成 される」（丹下，1963，p. 152）ものであると述 べている，スポーツに抢ける「根性」は，オリン ピックや世界大会の選手となる一流競技者に限ら ず，学校スポーツ，特に運動部活動における指導 にも反映されていったといえよう。

スポーツに抢ける「根性づくり」は，東京オリ ンピックに扔いて競技者の養成および強化のため に, 選手強化本部, スポーツ科学研究委員会が中 心となって考えられた経緯があった。その一方 で，オリンピック選手を指導した指導者たちが独 自の根性論を展開し，東京オリンピック以降の根 性の流行を後押ししたことが考えられる. スポー ツ指導に「根性」を取り入れた指導者には，日紡 貝塚女子バレーボールチーム「東洋の魔女」を率 いた大松博文があげられる。大松の著書「おれに ついてこい!」は，1963(昭和38)年に出版後べス トセラーを記録していることから，当時の人びと に広く知られていたといえよう。大松の独特な指
導論については，作田（1967）が以下のように 簡潔に言いあらわしている。

「『なせばなる』『勝負は勝たねばならぬ』『自 分のためにやれ』『人並以上に努力せよ』『自 分がしなくて誰がやる』『一日㤐れば回復は 三日』『病気は許されぬぜいたく』『けがに慣 れてしまえ』一これらの格律で固められた大 松イデオロギーは『根性』とそれをつくる 『ハード・トレーニング』ということばで要 約された.」(作田，1967，p. 270)

大松が実践した「ハードトレーニング」とは, 「自分自身に打ち勝つ日々の修練」(大松，1963， p. 103）であり，「そういうハードトレーニング によって，根性が，つをり “事を行なうに久しく 耐え忍ぶ精神の力をもった性質”が生まれてくる」 （大松，1963，p. 104）と述べられている. また， 根性養成のために，強烈な継続的行動や目的への 執着，その結果として人格のなかに「精神の力」 が生まれる，といった条件をあげている。

大松の著書「お扎についてこい!」の内容分析 を抢こなった山岸（1979）によれば，大松の主 張の中心テーマは, 精神力による目標達成にあ り，目標達成に向けてあらゆる手段が動員され， その副産物として人間形成および幸福がもたらさ れることであった注11)。大松のハードトレーニン グに象徵される「根性」論が受けいれられていっ た要因は，次のように考えることができよう。つ まり，大松が指導した日紡貝塚女子バレーボール チームは，国内にとどまらず世界で活躍し， 1962 (昭和37)年の世界選手権で優勝したことで 東京オリンピックに抢けるメダルの獲得が期待さ れるが，それをも実現したことによって，人びと に広く知られていったと考えることができる.

\section{3. 東京オリンピック以降の社会における「根 性論」の展開}

すでに検討したように，「根性」は，東京オリ ンピックを契機として競技者の養成や強化，その 成果としての勝利のための精神的基調として用い 
られるようになったと考えられる。一方で，この 時期に「根性」はスポーツ以外の領域でも取り上 げられている.

雑誌「児童心理」では，1965(昭和40)年 5 月 号で根性に関連する特集が組まれている。本明 （1965）は，「根性」を一般社会に抢ける仕事へ の意欲としてとらえている，また，その意欲をも って成果を出すことで社会の期待にこたえ，社会 的価值を生産していくことが「根性づくり」であ ると考えている。この「根性」は，教育界におい ては人間形成という視点から比較的長い時間経過 に打ける目標達成を目指す際の解決の一助となる 点に抢いて，その必要性が認められている(本明， 1965，p. 3). 心理学者であった本明は, 欲求. 願望・衝動等々いう動機の体系の成立・発展を考 え, 「根性」の心理学的メカニズムを, 心理学に おける「意志」の概念の下で説明している.

「児童心理」における同特集記事において，杉 山（1965）は，「根性」がスポーツの世界に端を 発し, 勝利への欲求とそのための猛練習が強調さ れたことで，「根性」はきたえられることによっ て身につくものであるということが確認されてい ったと述べている。杉山は，「根性」論の問題性 について, 資本主義社会における産業界の要求に 応じた人間的な資質の問題にひきよせた見解を示 している，具体的には，経済審議会の人的能力部 会の答申「経済発展に抢ける人的能力開発の課題 と対策」（1963）に打いて，この人間的な資質の 問題が明確にされている。答申では，「ハイ・タ レント」「中級技術者」「単純労働者」といった労 働力の育成が目指されて抢り，人間としての育成 ではなく，労働力としてみなされる人間の効率的 な養成が考えられていた。 また，特に力点が置か れたハイ・タレントの育成において，「すべてが 素質として先天的に備つているのではなく，後天 的な経験や努力によつて得られるものも多い」 （経済審議会，1963，p. 21）といわれているよう に，これらの資質は教育によって身につけられる ものであると考えられていた，杉山が述べている ように，東京オリンピックに抢ける「東洋の魔女」 の優勝がそれに拍車をかけ，スポーツに抢ける
「根性」が，資本主義社会のなかで生きる原則と して拡大解釈され, 求められる人間像についての 問題と関係をもち，教育と結びついたと考えるこ とができよう。

東京オリンピック以降, 社会に「根性」が受け いれられた背景には, 漫画やテレビ, 流行歌とい った大衆文化に括いて「根性」が取り上げられた ことが考えられる. 1966(昭和41) 年 5 月に「週 刊少年マガジン」で連載がはじまった「巨人の星」, 1967 (昭和 42 ) 年から「週刊少年キング」で連載 された「柔道一直線」では「根性」論が展開され ている。ほかにも，1968(昭和43)年から連載さ れた「アタック No. 1」や1969(昭和44)年から連 載された「サインは V!」は，大松博文と「東洋 の魔女」に影響を受けた作品であると考えられ る.テレビ番組でも，漫画のアニメ化で「巨人の 星」が1968(昭和43) 年 3 月から1971(昭和46)年 9 月まで放映され，「アタックNo. 1」，「サインは $\mathrm{V}$ !」も同時期に放映されている．漫画やアニメ では，いわゆる「スポ根」注12) というジャンルが 誕生しているように, 東京オリンピック後, ス ポーツにおける「根性」に関連した作品が流行し たといえる．先の新聞記事における「根性」の使 用状況を調查した際に，両紙とも1970(昭和45) 年から1971(昭和 46$)$ 年に打ける件数の上昇がみ られたが，これは上述の「スポ根」ジャンルの流 行に関連したものと推察される. 歌謡曲に関して は，美空ひばりの「柔」（1965）や水前寺清子の 「ゆさぶりどっこの唄」(1965)，「いっぽんどっ この唄」(1966), 村田英雄の「柔道一代」(1963), 「柔道水潡伝」(1965), 山田太郎の「新聞少年」 （1965）といった流行歌の歌詞は「根性」に通じ る内容を示しているといわれる（山岸ほか, 1979，pp. 232-233). 東京オリンピックを契機 として，スポーツ界で展開されてきた「根性」論 は，一般社会や教育，大衆文化に抢いても取り上 げられ，「困難にくじけない強い性質」「事を成し 遂げようとする強い気力」としての「根性」の定 着を後押ししたと考えることができよう.

本研究におけるこれまでの分析, 検討をふま え, 最後に課題 3)「根性」の意味使用が変容し 
ていった要因についての仮説を提示したい。「根 性」の意味使用が変容していく過程には，東京才 リンピックを成功に導くためにスポーツ体制が整 備され，「根性」が担い手の精神的基調として戦 略的に措定されていったことが指摘された。この ときに，スポーツに抢ける「根性」は競技者とし ての「人間つくり」や「人間形成」の問題として 取り上げられ，大島の主張に示されたように，東 京オリンピックを契機に新たなスポーツ界のアイ デンティティを構築しようとする意図があったこ とが推察された。一方で, 先の杉山の見解にみら れたように，高度経済成長を成し遂げるために， 社会に打ける人間的な資質の問題が取り上げら れ，労働力としてみなされる人間の効率的な養成 が考えられていた。すなわち，スポーツ界と経済 界および実生活において, 国際競争に勝利し, 目 標を達成するための「人間つくり」「人間形成」 を問題としていたといえる。これには，先の作田 が述べているように，実生活においてもスポーツ においても「成功の方法はどちらの世界でも同じ だという考え方」（作田，1967，p. 271）がなさ れていたといえよう。それゆえに，「根性」とい う言葉を採用した戦略的意図がそれぞれの発信主 体の側で一致していたと考えることができよう.

また，作田の見解をふまえれば，もうひとつの 考え方として，実生活に招ける（集団の）実力は スポーツにもあらわれるという「素朴な反映論」 （作田，1967，p. 271）があげられる.1953（昭 和28)年に日紡女子バレーボール部を創設するに あたって，当時の社長の意向が以下のように記さ れている.

「日紡はこんど，バレーボールを会社の看板 スポーツとしてやる方針を立てたのだが，や るからには, 絶対に強いチーム, 負けない チームにせにゃならん，その強弱によって社 運が判断される。どんどん強くなっていけ ば，世間から，日紡の社運は隆盛とみなさ れ，弱ければ，衰退の一路をたどっていると みなされる」(大松，1963，pp. 34-35）
上述のように，当時の企業体の実力は，又ポー ツの実力で評価されうるものとしてみなされてい たといえよう. 経営に余裕のある企業だからこ そ，スポーツに力を入れることができると考えら れたのであり，実際に日紡バレーボールチームの 歴史を引き継いだユニチカバレーボール部は，不 況の影響をうけて 2000 (平成12)年に休部を発表 している（海老原，2000，p. 915).

東京オリンピックに抢ける「東洋の魔女」をは じめとした競技者の活躍・勝利によって, スポー ツにおける「根性」論が，当時の時代状況を生き 抜くための原則として拡大解釈され, 高度経済成 長期に求められる人間像についての問題と関係を もったことが推察される. 敗戦による挫折・圭失 を経験し，困難に耐えて復興を果たし，国際競争 を勝ち抜いていく姿を，スポーツが競技者の身体 （勝利）を通じて示したといえよう。そして「新 しい人間的資質」が1960年代の社会に求められ たことで，「生まれついた人間の根本的な本質」 というそれまでの「根性」という言葉の意味使用 もまた，「困難に耐え抜く強い意志」，さらにはそ れが後天的に形成されうるという意味使用へと必 然的に変容していかなければならなかったと考え ることができよう.

\section{$\mathrm{N}$ ．本研究のまとめ}

本研究は，1960年代のわが国における「根性」 の意味使用が变容した契機を明らかにすることを 目的としていた．本研究に抢けるこれまでの考察 の結果，以下のようにまとめることができる.

戦前から戦後のはじめにかけて「こころだて, こころね，しょうね」といった，人間性や人間の 本質的な部分, 先天的に備わった性質といった意 味で，主に否定的な用語とともに使用されていた 「根性」という言葉が，1960年代の社会状況を背 景に，東京オリンピックを重要な契機として，後 天的に備わる「困難にくじけない強い性質」「事 を成し遂げようとする強い気力」というもうひと つの意味で, 主に肯定的な文脈における使用へと 転換していったことが実証的に示された。 また， 
東京オリンピックに抢ける競技者の精神的基調と して養成・強化の対象とされた「根性」は, 勝利 という目標達成のために精神を集中し, 困難に屈 せず継続する強固な意志のこととされ，その養成 には，ハードトレーニングといわれる猛練習が重 視された。 もとは先天的な人間性として用いられ ていた「根性」という言葉がスポーツに転用され たことで，後天的に形成されるもの・養成できる ものと捉えられ，競技者としての「人間つくり」 や「人間形成」の問題として，1960年代の社会 に打ける人間的な資質，人的能力の開発の問題と も関連づけられ，戦略的に推進されていったこと が考えられた．以上のことから，1960年代にお ける「根性」の意味使用の変容には，スポーツ界 とりわけ東京オリンピックが重要な役割を果たし たといえよう。

\section{注}

注 1）三本松（2003）は,「スポーツの発展過程にお いて，その国の風土，文化，国民性等が浸透して いくことによって，その国独自のスポーツに対す る価值観や意識, 態度等が形成されるという文脈 に掞いて，究極的には，わが国に特有の，あるい は固有のスポーツ観あるいはスポーツ行動様式等 を明らかにする」という目的に扔いて，「日本人 のスポーッ観」や「スポーッの日本的特性」を 「日本的スポーツ論」に統一して用いている.

注 2）たとえば，本文で後述する見田（1965）も引用 しているが，「近代日本思想史講座」第 1 巻の冒 頭において以下の記述が確認できる.

「経済は戦前の水準に追いつき, 追い越したかも しれないが，敗戦によってくずれたわれわれの基 本的な価值体系は，元にもどらなかったし，もど らぬことは当然だとしても，それに代る別の価值 体系がつくられてもいない，いろいろの選択の努 力はあるが，それらは有効に統一化へ向わない で，バラバラに存在している．精神に関していえ ば，私たちはまだ敗戦の衝撃からいくらも回復し ていない」(竹内, 1959, p. 2)

注 3）五十嵐（2007）は, 戦後日本の歴史を背景とし て，過去を想起するプロセスの検証を行なううえ で「記憶」を歴史の不可分な一部として認め, 歴史という概念そのものの再検討を試みている. 五十嵐は，過去を再構築しようとした多くの試み
を，戦後日本の文化的な言説空間にたどり，過去 を記憶するなかで敗戦による「挫折・喪失」が中 心的な位置にあることを明らかにしている。

注 4）安丸によれば，「通俗道徳」は幕末から明治に かけて広汎な民衆のうちにみられた日常的な生活 規範, 自己規律を中心とした倫理のことである (安丸，1974，p. 4).「通俗道徳」が指摘された ことには，次のような歴史的状況がかかわってい るといえる。すなわち，わが国における近世後期 において, 封建権力や商業高利貸資本による過酷 な収奪を経済史的要因として荒廃する村々が続出 したといわれ，家や村の没落を克服しなければな らないという切迫した状況が, 新たな生活態度の 樹立，民衆思想の形成という課題に直面させたと 考えられる.

注 5) 中井 (1982) は, 精神病理学の視点から日本人 の勤勉・工夫を支えている性格構造とその歴史的 背景について考察を行なっている. 中井は, うつ 病好発性格として承認されている下田光造の「執 着気質」やテレンバッハの「メランコリー型」の 特徵記載に，広範囲の職能者の仕事への関わり 方，職場の人間関係が共通してあげられているこ とを指摘する，そのなかで，中井は昭和前期に精 神科医として活動した下田光造が「執着気質者」 について記載した内容に, 安丸の「通俗道徳」に 共通する生活倫理・生活道徳をみいだしている. 中井は, この生活倫理・生活道徳を「執着（性） 気質的職業倫理」とよんでいる（中井，1982， pp. 43-44). 安丸（1996）もまた, 中井の「執着 (性) 気質的職業倫理」が通俗道徳にほほ照応す るものであることを認めている（安丸，1996, p. 94).

注 6) 国語辞典の内容については，以下の辞典にあた り，内容の検討を行なった．な抢，本文中で引用 した辞典の記載内容は原文のまま示している. (発刊年順)

「言海」(1891)，「日本大辞林」(1894)，「辞林」 (1907)，「大日本国語辞典」(1928)，「大言海」 (1933)，「広辞林」(1934)，「辞苑」(1935)，「言 苑」(1938), 「言林」(1949), 「広辞苑」(1955), 「新言海」(1959), 「広辞苑（第 2 版）」(1969), 「日本国語大辞典」(1974)，「広辞苑（第 3 版）」 (1983)，「日本国語大辞典（第 2 版）」(2001）, 「広辞苑（第 6 版)」(2008)

注 7） 日本国語大辞典第 2 版（2001）の「語誌」によ れば，「根性」は本来仏教語であり，好悪のいず れの印象も伴わない言葉であったが，次第に悪い 
意味を伴ったかたちで用いられ，それが現代にま で続いているといわれている。その一方で，ス ポーツや教育との関わりにおいて，悪い「根性」 を鍛え直すという観点がおこり，鍛えられた「根 性」から，「根性」自体が好ましい意味で用いら れることとなったと説明されている（ジャパンナ レッジプラス「日本国語大辞典」http://www. $\mathrm{jkn} 21$.com/body/display/).

注 8） 新聞記事検索については，以下の朝日新聞と読 売新聞のオンラインデータベースを使用した (キーワードは「根性」を入力した). また，検索 範囲は国語辞典の内容との照応を考慮に入れ，明 治期の両紙の創刊から昭和期まで（1870年代から 1980年まで）とした.

朝日新聞「聞蔵 IIビジュアル」

http://database.asahi.com/library2/

検索結果：345件（1879年一1980年）

読売新聞「ヨミダス歴史館」

https://database.yomiuri.co.jp/rekishikan/ 検索結果：608件（1875年一1980年）

注 9）新聞記事における「根性」の意味使用の転換は 1960年代はじめ頃であったのに対して，辞書の記 載に颃いて変化が確認されたのは1970年代はじめ 頃であった。この時間的差異については，「根性」 の意味使用の転換が確認され，辞書に採録される までには一定のタイムラグが生じていたと推察さ れた.

注10） 1964 (昭和39)年 5 月23日の選手強化本部総会 における組織編成の承認時点での心理部会は下記 の人員で構成された.（スポーツ科学研究委員会, 1965, p. 22)

スポーツ科学研究委員会 (心理部会)

松井三雄, 松田岩男, 清原健司, 大川信明，小笠 原慈瑛, 成瀬悟策, 瀬谷正敏, 藤田厚, 小林晃 夫，太田哲男

注11）山岸（1979）は，内容分析を適用することによ って，価值や態度コンプレックス一般の分析のた めの方法の開発を試みており，「根性主義」はそ の適用例として位置づけられている．検討の結果 として，以下の点が「根性主義」の性質として述 ベられている.

「(1)目標を達成するためには，禁欲すなわち己に 克つことが最も大切であり, 次に努力と精神力が 大切である. 忍耐, 持続力, 自己犠牲の精神, 義 務の遂行なども目標達成のために必要であるが, 先の三つほど重要ではない.

(2)努力し，苦労すれば，幸福になることができ
る、また幸福を得るためには, 強い精神力も必要 である。

(3)持続性，つまり同じことを繰り返し行なうこと により，また自己犠牲の精神を発揮することによ

り，人間形成がなされる」(山岸，1979，p. 193）

注12)「スポ根」は，スポーツ漫画の一ジャンルとし

て，「スポーツ $=$ 熱血 $=$ 根性 $=$ 友情 $=$ 努力 $=$ 青春 ドラマ $=$ 少年漫画」（夏目，1991，p. 50）という 図式で捉えられている。このジャンルは, 努力や 忍耐でスポーツに取り組み, 困難を乗り越えて選 手としてのパフォーマンスの向上へ前進し続ける 過程を中心に描かれた作品をさすといえる. 本文 でも述べているように,「スポ根」は1960年代か ら70年代に隆盛した劇画の影響を受けて流行した ことが考えられる。

\section{文献}

朝日新聞（1879） 5 月30日付 朝刊. 朝日新聞 (1893) 9 月 8 日付朝刊. 朝日新聞（1894）2月11日付 朝刊. 朝日新聞（1910）4月19日付 朝刊. 朝日新聞（1915）1月24日付 朝刊. 朝日新聞（1915）10月12日付 朝刊. 朝日新聞（1960）5月11日付 朝刊. 朝日新聞（1960）11月13日付 朝刊. 朝日新聞（1961）11月 1 日付 夕刊. 朝日新聞（1964）10月15日付 朝刊. 朝日新聞（1964）10月22日付 朝刊. 朝日新聞（1965）10月22日付 夕刊. 朝日新聞 (1966) 8 月 5 日付 夕刊. 浅川正一 (1968) 体育の学習と精神力. 学校体育, 21 (6) : 22-25.

大松博文（1963）抢れについてこい!. 講談社 : 東京. デビットノッター・竹内 洋 (2001) スポーツ・エリー

ト・ハビトゥス. 杉本厚夫編 体育教育を学ぶ人の ために。世界思想社 : 京都, pp. 4-23.

海老原 修 (2000) 高度経済成長を支えた呪術：大松

博文とその論理. 体育の科学, $50(11)$ : 913-917.

五十嵐惠邦 (2007) 敗戦の記憶：身体·文化·物語 1945-1970. 中央公論新社 : 東京.

金沢庄三郎編（1907）辞林. 三省堂書店：東京.

金沢庄三郎編（1934）広辞林. 三省堂 : 東京.

経済審議会編（1963）経済発展における人的能力開発 の課題と対策 戦後教育改革構想 I 期 8 . 日本図書 センター：東京.

岸野雄三（1968）日本のスポーツと日本人のスポーツ

観. 体育の科学, 18(1): 12-15. 
松田岩男（1971）根性の心理. 体育の科学, 21(9)： 572-574.

見田宗介（1965）現代日本の精神構造. 弘文堂 : 東京. 物集高見（1894）日本大辞林. 清水卯三郎：東京.

本明 寛（1965）根性の心理学. 览童心理, 19(5): 114.

中込四郎（1984）スポーツに抢ける精神力の分析：根

性を考える。体育の科学，34(2)：84-88.

中井久夫（1982）執着気質の歴史的背景 : 再建の倫理

としての勤勉と工夫. 分裂病と人類. 東京大学出版 会 : 東京, pp. 39-87.

夏目房之介（1991）消えた魔球 熱血スポーツ漫画は いかにして燃えつきたか，双葉社：東京.

日本大辞典刊行会編 (1974) 日本国語大辞典 第 8 巻. 小学館 : 東京.

日本国語大辞典第二版編集委員会 - 小学館国語辞典編 集部編（2001）日本国語大辞典第 2 版 第 5 巻. 小 学館 : 東京.

大島鎌吉・東海林武雄（1964）秒読みに入った民族の 祭典 (対談) 特集・技能五輪の成果と今後の課題.

経営者, 18(10): 64-69.

太田哲男（1968） スポーツと根性。体育科教育， 16 (6): 44-45.

大梘文彦 (1891) 言海. 大梘文彦 : 東京.

大梘文彦 (1933) 大言海 (第 2 巻). 冨山房 : 東京.

大梘文彦 (1959) 新言海. 日本書院 : 東京.

坂上康博（2001）にっぽん野球の系譜学. 青弓社 : 東 京.

作田啓一（1967）バレーボールの中の共同体．恥の文 化再考. 筑摩書房 : 東京, pp. 268-279.

三本松正敏（2003）日本的スポーツ論再考. 福岡教育 大学紀要 52 第 5 分冊 : 51-64.

新村出編（1935）辞苑. 博文館 : 東京.

新村出編 (1938) 言苑. 博文館 : 東京.

新村出編（1949）言林 昭和24年版. 全国書房 : 京都.

新村出編（1955）広辞苑. 岩波書店：東京.

新村出編（1969）広辞苑（第 2 版）。岩波書店：東京.

新村出編（1983）広辞苑（第 3 版）。岩波書店: 東京.

新村出編（2008）広辞苑（第6 版）. 岩波書店：東京.

菅原 禮 (1976) 日本的スポーツ風土の社会学的考察.

新体育, 46(4): 22-25.

杉山明男（1965）根性論と現代社会一根性論を必要と する社会的背景一. 児童心理, 19(5): 15-23.

スポーツ科学研究委員会編（1965）東京オリンピック スポーツ科学研究報告.

高橋亀吉（1964）スポーッと根性について. 新体育,
34(11): 130-135.

竹内 好（1959）講座をはじめるに当って．家永三郎

編 近代日本思想史講座 1 歴史的概観. 筑摩書 房: 東京, pp. 1-12.

丹下保夫（1963）体育技術と運動文化．大修館書店：

東京.

東京オリンピック選手強化対策本部（1962）いわゆる

「根性」について (座談会). OLYMPIA．3(3):210.

上田万年 ·松井簡治 (1928) 大日本国語辞典 第 2 巻.

冨山房 : 東京.

上杉正幸（1982）日本人のスポーツ価值意識と道・修

行の思想. 体育・スポーツ社会学研究， 1: 39-57.

山岸俊男（1979）根性主義一「おれについてこい!」

の内容分析一, 一橋論叢, 81(2): 181-197.

山岸俊男・市川孝一 - 島田幸男 (1979）高度成長期の

社会心理の一側面一「根性主義」試論一。佐藤毅ほ

加編 現代の社会心理. 誠信書房 : 東京, pp. 231249.

安丸良夫 (1974) 日本の近代化と民衆思想. 青木書店：

東京.

安丸良夫（1996）〈方法〉としての思想史．校倉書房：

東京.

読売新聞（1875）8 月10日付 朝刊.

読売新聞 (1928) 6 月16日付 朝刊.

読売新聞（1961）10月16日付 朝刊.

読売新聞（1961）11月10日付 朝刊.

読売新聞（1961）11月14日付 朝刊.

読売新聞（1964）8 月10日付 朝刊.

読売新聞（1964）10月23日付 朝刊,

読売新聞 (1965) 2 月 1 日付 夕刊.

読売新聞（1965） 3 月 3 日付 朝刊.

(HP)

朝日新聞（「聞蔵 II ビシュュア」）http: // database. asahi.com/library2/（参照日2012年 5 月16日）

読売新聞（「ヨミダス歴史館」）https: // database. yomiuri.co.jp/rekishikan/（参照日2012年 5 月16日）

知識探索サイト シシャパンナレッジプラス Japan knowledge ${ }^{+}$http: // www.jkn21.com / stdsearch / displaymain（参照日2012年 5 月16日）

$\left(\begin{array}{l}\text { 平成 } 23 \text { 年 } 2 \text { 月 } 7 \text { 日受付 } \\ \text { 平成 } 24 \text { 年 } 2 \text { 月 } 16 \text { 日受理 }\end{array}\right)$

Advance Publication by J-STAGE

Published online 2012/4/3 